Original Article

\title{
LOW SERUM IRON LEVEL AND LYMPHOCYTE DNA DAMAGE AMONG ADULTS.
}

\author{
Pinak Samal ${ }^{1}$, Suchetha Kumari N. ${ }^{2}$, Indira R. Samal ${ }^{3}$, Kathyayani Sathish ${ }^{4}$ \\ ${ }^{1}$ Department of Biotechnology, M anipal Institute of Technology, Manipal University, M anipal, Karnataka, India. \\ ${ }^{2}$ Professor, Department of Biochemistry, K.S. Hegde Medical Academy, Nitte University, Mangalore, Karnataka, India. \\ ${ }^{3}$ Asst Professor, Department of Biochemistry, K.S. Hegde M edical Academy, Nitte University, M angalore, Karnataka, \\ India., ${ }^{4}$ Lecturer, Department of Biochemistry, K.S. Hegde Medical Academy, Nitte University, \\ Mangalore, Karnataka, India \\ Correspondence: \\ Pinak Samal \\ Mobile : +91 88845 58297, E-mail : pinakrsamal@ gmail.com
}

\begin{abstract}
:
Cellular DNA damage has been related to both external and internal factors. Serum Iron is one of the factors which has importance in the oxidative status of the cell. Higher iron levels have been found to be associated with imbalance in the oxidation-antioxidant system and has been associated with DNA damage due to oxidative stress. However, oxidative stress and DNA damage has also been reported in iron deficiency states, in some studies. It appears that the body iron level should be maintained at optimum level for a balanced scenario and both iron excess as well as iron deficiency states may be associated with oxidative stress and attendant DNA damage. In this study, the blood collected from eighty four volunteers (fifty six males and twenty eight females ) was subjected to estimation of serum iron (Bathophenanthroline method). Also, Lymphocyte DNA damage was ascertained by Alkaline Comet Assay method (Qualitative assessment only). The range of serum iron in this group was found to be between $39.91 \mu \mathrm{gm} / \mathrm{dl}-93.55 \mu \mathrm{gm} / \mathrm{dl}$ in females and between $37.7 \mu \mathrm{gm} / \mathrm{dl}-133.63 \mu \mathrm{gm} / \mathrm{dl}$ in males. Very high as well as very low serum iron was not found in this study group as the volunteers were all ambulatory and asymptomatic. Among the volunteers who had serum iron less than $50 \mu \mathrm{gm} / \mathrm{dl}(\mathrm{N}=17)$, eleven (64.7\%) had evidence of DNA damage as per the alkaline comet assay. Among the group having serum iron 51-70 $\mu \mathrm{gm} / \mathrm{dl} \quad(\mathrm{N}=34)$, fourteen (41\%), had evidence of DNA damage. Similarly, among the group, having serum iron 71-90 $\mu \mathrm{gm} / \mathrm{dl}$ ( $N=27$ ), evidence of DNA damage was seen in ten (37\%) persons. There were very few persons with serum iron more than $91 \mu \mathrm{gm} / \mathrm{dl}(\mathrm{N}=6)$ and out of them two had evidence of DNA damage. In total, out of 84 persons, thirty seven (44\%) had evidence of DNA damage as per alkaline comet assay. This trend of inverse dose response relationship was also noticed separately among males as well as in females. This is a preliminary exploratory study in India (although a few similar reports also exist in studies done in other parts of the world) and admittedly, had not taken into account of other confounding factors. Nevertheless, the findings suggesting association of low serum iron level and DNA damage, which has also been reported in some earlier studies at other parts of the world, need further examination through larger controlled studies.
\end{abstract}

Keywords : DNA damage, Serum Iron, Lymphocyte DNA, Iron Deficiency Anemia, Oxidative Stress, M utagenesis

\section{Introduction:}

Any cell of the body constantly performs functions, which are biochemical in nature, to keep itself alive. As a byproduct of these biochemical reactions, potentially harmful molecules known as reactive oxygen species or free radicals are generated. Besides normal metabolic reactions, free radicals are also generated on exposure to external factors like components of tobacco smoke and air pollutants and ionizing radiations etc. Free radicals serve important physiological functions in the body as they signal the immune system to scavenge the area particularly to remove harmful cellular matter which might be toxic to the body. The free radicals are neutralized by the anti-oxidant system (both from endogenous and exogenous sources) so as to maintain the balance needed for health. This balance of oxidative state and anti oxidants may become impaired in many conditions. Oxidative DNA modification is a detectable change occurring due to free radical stress in the human body ${ }^{(1)}$. One of the micro nutrient which has relationship with the oxidative state of the body is iron.

Iron is an important elemental micronutrient which is essential for the human body. Regular iron intake is through diet containing food items such as Spinach, 
Capsicum and other green leafy vegetables, as well as from animal foods. However, exit routes of iron from the body are limited. It is not excreted by the kidney or in the bile. Some amount is excreted by sweat. Excess of iron can create complications in the body and hence, the human body controls the absorption of iron from the gut itself. A number of physiological defence mechanisms in the body minimize the amount of free iron in the human body because any type of free metal ions including that of iron can be toxic to the body.

Metals such as Iron can exist in transition state in the body. If released from a damaged tissue, it may undergo Fenton reaction with less reactive agents to form highly reactive radicals like $\mathrm{OH}$. The reaction is ${ }^{(2)}$.

$$
\mathrm{Fe}^{2+}+\mathrm{H}_{2} \mathrm{O}_{2} \rightarrow \mathrm{Fe}^{3+}+\mathrm{OH}^{-}+\mathrm{OH}
$$

Thus, metal ion, (including that of iron) as well as other micronutrient imbalance in the body, may lead to DNA damage and mutational changes. Increased Oxidative Stress and DNA damage has been reported in earlier studies both in states of iron deficiency as well as in iron overload $^{[3,4]}$. There are reports that iron deficiency might contribute to DNA damage because of the impairment of many iron-dependent metabolic functions which lead to protection and maintenance of the genome ( For exampleimmune responses against cancer cells, metabolism of toxic compounds, and redox regulation of DNA biosynthesis and repair) ${ }^{[5]}$. Thus, in the state of both iron overload as well as in iron deficiency state, DNA damage might occur. This DNA damage is not necessarily permanent because the repair mechanism to the damage also goes on in the body continuously. In this context, when many scientific literature exist as to how excess of iron is responsible for oxidative stress and DNA damage, some studies also suggest DNA damage might occur in iron deficiency states. In India, such study is not found among individuals with iron deficiency and the present study was conducted to explore the relationship between serum iron and DNA damage. The objectives of this study were to estimate the level of serum iron among a group of adults and to study the DNA damage of lymphocytes in the same group by qualitative methods and also to correlate the relationship between serum iron and lymphocyte DNA damage in the study population.

\section{Materials and Methods :}

The Study was conducted in the year 2011 in Mangalore . Eighty six adult volunteers in the age group 23 years to 65 years were included in the study (fifty six males and twenty eight females) .The sampling was purposive sampling. All the individuals were ambulatory and asymptomatic. Ethical considerations were duly followed. Five millilitre of blood was collected from each volunteer and the serum, after separation, was subjected to estimation of serum iron using Bathophenanthroline method $^{(6)}$. As per literature, the normal range of serum iron is expected to be between $37 \mu \mathrm{gm}-145 \mu \mathrm{gm} / \mathrm{dl}$ in females and between $59 \mu \mathrm{gm}$ - $158 \mu \mathrm{gm} / \mathrm{dl}$ in males using this method ${ }^{(7)}$. Also, lymphocyte DNA damage was ascertained by "Alkaline Comet Assay" method. Only qualitative DNA damage was studied using the method as described by Singh NP et al ${ }^{(8)}$. The accompanying figure-1 shows the picture of lymphocytes of normal individuals without DNA damage where as the figures 2 and 3 show the picture of DNA damage in lymphocytes as per Alkaline Comet Assay.

\section{Results :}

In this study, 84 individuals were included ( 56 males and 28 females ). The range of serum iron in the group was found to be between $39.91 \mu \mathrm{g}-93.55 \mu \mathrm{g} / \mathrm{dl}$ in females and between $37.7 \mu \mathrm{g}-133.63 \mu \mathrm{g} / \mathrm{dl}$ in males. Very low serum iron was not found in the group as they were all ambulatory and asymptomatic volunteers. Similarly, very high serum iron was also not found in the group. The results of the study are presented in the following tables ( 1 to 3 ).

As is seen from Table-1, out of Seventeen individuals having serum iron level less than $50 \mu \mathrm{gm} / \mathrm{dl}$, eleven $(64.7 \%)$ did show evidence of DNA damage. Where as among the Thirty four individuals who had serum iron level between 51-70 $\mu \mathrm{gm} / \mathrm{dl}$, DNA damage was seen in fourteen (41\%) persons. Also, among twenty seven persons having serum iron between 71-90 $\mu \mathrm{gm} / \mathrm{dl}$, DNA damage was found in ten individuals (37\%). There were very few persons ( only six) with serum iron more than $91 \mu \mathrm{gm} / \mathrm{dl}$ in 
this group and among them, two persons showed evidence of DNA damage. In total, out of eighty four persons studied, thirty seven (44\%) did show evidence of DNA damage. From the results in the table, there appears to be an inverse dose-response relationship between the level of serum iron and the DNA damage. There was no person in the study population with very less or excess of serum iron. The range of serum iron observed in the study group was between $39.91 \mu \mathrm{g}-93.55 \mu \mathrm{g} / \mathrm{dl}$ in females and between $37.7 \mu \mathrm{g}-133.63 \mu \mathrm{g} / \mathrm{dl}$ in males

The results in the table-1 were subjected to statistical analysis by applying $\chi^{2}$ test. However, statistically, significantly difference could not be found ( at $p=0.05$ level). Nevertheless, the trend showing inverse dose response relationship was evident, indicating that more proportion of persons having low serum iron were having lymphocyte DNA damage in comparison to those who had normal serum iron. This trend was also visible when the study population was broken down to males and females and the groups were studied separately.

Table-2 summarises the level of serum iron and DNA damage among males in the study group. There were fifty six males in the study group, out of which, nineteen (34\%) had evidence of DNA damage. It was found from the table that among the males who had serum iron less than $50 \mu \mathrm{gm} / \mathrm{dl}(\mathrm{N}=07)$, four $(57 \%)$ had evidence of DNA damage. This was in comparison to the males who had serum iron between 51-70 $\mathrm{ggm} / \mathrm{dl}$, among which, DNA damage was observed in $31 \%$ of people. On applying $\chi^{2}$ test to the data in the table, statistically, significant difference could not be elicited ( at $p=0.05$ level). However, the trend of inverse relationship, was visible and was consistent with other studies also.

Table 3 revealed that ten women were having serum iron level less than $50 \mu \mathrm{gm} / \mathrm{dl}$ and seven of them (70\%) had evidence of DNA damage. Eight women had serum iron level between $51-70 \mu \mathrm{gm} / \mathrm{dl}$ and Six of them (75\%) had evidence of DNA damage. In the group having serum iron between 71-90 $\mathrm{\mu gm} / \mathrm{dl}$, there were eight women and four of them (50\%) had DNA damage. In total, out of 28 women, eighteen (64\%) had evidence of DNA damage. Although it is visible from the table that DNA damage was more among women who had serum iron less than $50 \mu \mathrm{gm} / \mathrm{dl}$, in comparison to other groups. However, statistically, applying $\chi^{2}$ test, the distribution among different groups in the table were not found to be significant ( at $p=0.05$ level) The probable reason has been discussed under earlier tables.

\section{Discussion :}

DNA damage in conditions of iron excess as well as iron deficiency has been reported in earlier literature. In conditions of excess iron, DNA damage occurs and there are plenty of reports in this regard. Role of iron and oxidative stress has been reviewed elsewhere by Esther Casanueva and Fernando E. Viteri ${ }^{(11)}$

Mehmet Aslan et al, ${ }^{(5)}$ reported in 2006,(on a study conducted in Turkey on 22 females with iron deficiency anaemia and 22 healthy females), that lymphocyte DNA damage in patients with iron deficiency anaemia was significantly higher than controls $(p<0.05)$, . Both oxidative stress and DNA damage were found to be increased in individuals with iron deficiency anaemia. Increased oxidative stress appeared to be an important factor that induce DNA damage in the individuals with iron deficiency anaemia.

Jong-Ha Yoo et $\mathrm{al}^{(9)}$, investigated the oxidative status in iron deficiency anaemia in 2009 and reported that the oxidant activity in patients with iron deficiency anaemia was significantly higher than controls $(P<0.05)$. After treatment, oxidant, antioxidant, and catalase activity reached the levels of the control group, and no significant differences were observed among groups._The results of their study supported the hypothesis that there was higher oxidative stress in iron deficiency anaemia. However, the authors mentioned that there were limited number of cases included in their study and they suggested that more studies might be required to confirm the results.

There are also studies where it was found that DNA damage among children with iron deficiency was lower than children who did not have anaemia. In a study conducted 
by Aksu B Y et al, ${ }^{(4)}$ in 2010, which included twenty seven children with IDA and twenty healthy children. Before iron administration, the frequency of DNA strand breaks in the children with IDA was found to be lower than those in the control group $(P<0.05)$. After 12 weeks of iron administration, the frequency of DNA strand breaks were found to be increased $(P<0.01)$. No significant association was determined between DNA damage parameters and hemoglobin, hematocrit, serum iron, total iron binding capacity, and ferritin. Hence, as per this study, frequency of DNA damage was found to be less in iron deficiency state in comparison to those with normal iron reserve. Prá $D$, Rech Franke SI, Pegas Henriques JA, Fenech $\mathrm{M}^{(10)}$ in 2009, reviewed the available research papers regarding possible link between iron deficiency and gastro intestinal carcinogenesis. They concluded that there was evidence suggesting links between iron deficiency and increased oxidative stress and DNA damage,. They also suggested that this might increase the risk of carcinogenesis, especially in the gastrointestinal (GI) tract. Basing on clinical, epidemiological, and experimental evidence, the authors discussed how iron deficiency might contribute to increased cancer risk through the impairment of several iron-dependent metabolic functions that are related to genome protection and maintenance (e.g., immune responses against cancer-initiated cells, metabolism of toxic compounds, and redox regulation of DNA biosynthesis and repair).

In the current study, the range of serum iron was found to be between $39.91 \mu \mathrm{g}-93.55 \mu \mathrm{g} / \mathrm{dl}$ in females and between $37.7 \mu \mathrm{g}-133.63 \mu \mathrm{g} / \mathrm{dl}$ in males. Very low serum iron was not found in the group as they were all ambulatory and asymptomatic volunteers. Similarly, very high serum iron was also not found in the group. On analysis of data, it was found that proportion of persons with DNA damage was more among persons who had serum iron less than $50 \mu \mathrm{gm}$ / $\mathrm{dl}$ in comparison to the group who had serum iron of more than $70 \mu \mathrm{gm} / \mathrm{dl}$. This trend was visible when the data was analyzed for the whole group as well as when the group was broken down to males and females and the results of each group were analyzed separately. There was no person with high / very high serum iron. Among the other members, there was inverse relationship between serum iron and DNA damage, suggesting that Iron deficiency state might be associated with higher rate of DNA damage.

The results of the study were subjected to statistical analysis by applying $\chi^{2}$ test. In spite of the trend of inverse relationship between level of serum iron and proportion of persons having DNA damage which was observed from the study, when statistical test ( $\chi^{2}$ test) was applied to the distribution of the results in the tables. However, the distribution was not found to be statistically, significantly ( at $p=0.05$ level). This was true when the results were analysed for the whole group or even separately for males and females. This could have been due to the small numbers in our sample or even due to selection criteria ( because purposive sample was taken for this study which included those volunteers only who were asymptomatic and ambulatory). The selection criteria of inclusion of only ambulatory and asymptomatic volunteers might have missed several persons whose serum iron might be too low and the results might have been affected due to it. Nevertheless, the trend showing inverse dose response relationship was evident, indicating that more proportion of persons having low serum iron were having lymphocyte DNA damage in comparison to those who had higher serum iron ( but within normal range ). This trend was also visible when the study population was broken down to males and females and the groups were studied separately.

This study was an exploratory study in India and rigorous sampling methods had not been followed. Similarly, the study also had not taken into account the other confounding factors which might have had impact on DNA damage. For example, confounding variables like smoking or occupational exposure to mutagens etc. which have potential to distort the results, have not been considered in this study. While reviewing the literature also it was found that in many other studies also similar deficiencies were present. Hence, results of this study should be interpreted keeping in mind these factors. 


\section{Conclusions:}

Diverse literature exists as regards iron deficiency state of the body and DNA damage. Some studies, suggest that DNA damage and iron deficiency state occur concurrently where as some others found that DNA damage was seen less in iron deficiency states. This study was conducted on eighty four individuals ( 56 males and 28 females) to study the relationship between low serum iron and DNA damage. It was observed that more proportion of individuals having serum iron less than $50 \mu \mathrm{gm} / \mathrm{dl}$, were having DNA damage in comparison to the individuals having higher serum iron ( i.e. serum iron higher than $70 \mu \mathrm{gm} / \mathrm{dl}$. The results were consistent when the whole group was considered together or when it was broken down to sub groups of males and females and the results were analyzed separately. However, such observed differences were not statistically significant. The reason for this could be due to certain weaknesses in the study design. Since it was an exploratory study, it had not followed elaborate sampling methods and the study did not have individuals with very low and very high serum level. All the individuals included in the study were ambulatory and asymptomatic volunteers and this might have contributed to dilution of the results. Further, this study also did not take into account the confounding variables which might have contributed to DNA damage of their own other than low serum iron. Nevertheless, the trend that was visible from the study suggests that low serum iron and iron deficiency anaemia might be occurring concurrently and more controlled studies are essential to prove the association between them. Even during review of literature, it was found that appropriate sampling / control of confounding factors were lacking in many studies and these might be the reason for diverse findings on the association. Hence, it is suggested that more controlled studies with more number of individuals need to be done on the problem. Adequate sample of persons with very low and very high serum iron also need to be included in the study. Besides, the other confounding factors which might have contributed to DNA damage, need to be taken into account and should be matched among the participants while interpreting the results of association between low serum iron and DNA damage.

\section{Acknowledgement:}

The authors acknowledge the co-operation extended by the volunteers without which, this study would not have been possible. Further, the authors acknowledge with thanks the help of Mrs. Sharada V; Lecturer in Statistics in the Department of Community Medicine of $\mathrm{K} S$ hedge Medical Academy, Mangalore, for her help in statistical analysis.

Table- 1 showing the DNA damage among the total study population, according to level of serum iron

\begin{tabular}{|l|rr|rr|r|}
\hline $\begin{array}{l}\text { Serum Iron } \\
\text { Level }(\mu \mathrm{g} \mid \mathrm{dl})\end{array}$ & \multicolumn{2}{|c|}{$\begin{array}{c}\text { Total with } \\
\text { DNA damage }\end{array}$} & \multicolumn{2}{|c|}{$\begin{array}{c}\text { Total without } \\
\text { DNA damage }\end{array}$} & $\begin{array}{c}\text { Total } \\
\text { number }(\mathrm{N}=84)\end{array}$ \\
\hline$<50$ & $11(64.7 \%)$ & \multicolumn{2}{|c|}{$6(33.3 \%)$} & $17(100 \%)$ \\
\hline $51-70$ & $14(41 \%)$ & 20 & $(59 \%)$ & $34(100 \%)$ \\
\hline $71-90$ & 10 & $(37 \%)$ & 17 & $(63 \%)$ & $27(100 \%)$ \\
\hline $91-110$ & 1 & $(25 \%)$ & 3 & $(75 \%)$ & $4(100 \%)$ \\
\hline$>110$ & 1 & $(50 \%)$ & 1 & $(50 \%)$ & $2(100 \%)$ \\
\hline TOTAL & 37 & $(44 \%)$ & 47 & $(56 \%)$ & $84(100 \%)$ \\
\hline
\end{tabular}

$\chi^{2}$ test was applied to the figures in the table. However, the distribution was not statistically significant at $p=0.05$ level. Nevertheless, the trend indicating that higher proportion of individuals with low serum iron did exhibit DNA damage, is evident in the table.

Table 2: Showing level of serum iron and DNA damage among males in the study group

\begin{tabular}{|c|c|c|c|}
\hline $\begin{array}{l}\text { Serum Iron } \\
\text { Level }(\mu g|d|)\end{array}$ & $\begin{array}{l}\text { Males with } \\
\text { DNA damage }\end{array}$ & $\begin{array}{l}\text { Males without } \\
\text { DNA damage }\end{array}$ & $\begin{array}{c}\text { Total } \\
\text { number }(\mathrm{N}=56)\end{array}$ \\
\hline$<50$ & $04 \quad(57 \%)$ & $03 \quad(43 \%)$ & 07 (100\%) \\
\hline $51-70$ & $08 \quad(31 \%)$ & $18 \quad(69 \%)$ & $26(100 \%)$ \\
\hline $71-90$ & 06 (31.6\%) & $13(68.4 \%)$ & $19(100 \%)$ \\
\hline $91-110$ & 0 & $2(100 \%)$ & 02 (100\%) \\
\hline$>110$ & $01 \quad(50 \%)$ & $01 \quad(50 \%)$ & 02 (100\%) \\
\hline TOTAL & 19 (34\%) & $\begin{array}{ll}37 & (66 \%) \\
\end{array}$ & 56 (100\%) \\
\hline
\end{tabular}

As can be seen from this table (Table-2), higher proportion of males, who had low serum iron, exhibited DNA damage. However, when $\chi^{2}$ test was applied to the groups in the table, it was not found to be statistically significant at $p=0.05$ level 


\section{Table-3 showing serum iron and DNA damage among females in the study group}

\begin{tabular}{|l|rl|rl|c|}
\hline $\begin{array}{l}\text { Serum Iron } \\
\text { Level }(\mu \mathrm{g} \mid \mathrm{dl})\end{array}$ & \multicolumn{2}{|c|}{$\begin{array}{c}\text { No. of females } \\
\text { with DNA damage }\end{array}$} & \multicolumn{2}{|c|}{$\begin{array}{c}\text { No. of females } \\
\text { without DNA damage }\end{array}$} & $\begin{array}{c}\text { Total number of } \\
\text { females (N =28) }\end{array}$ \\
\hline$<50$ & \multicolumn{2}{|r|}{$(70 \%)$} & 3 & $(30 \%)$ & $10(100 \%)$ \\
\hline $51-70$ & 6 & $(75 \%)$ & 2 & $(25 \%)$ & $08(100 \%)$ \\
\hline $71-90$ & 4 & $(50 \%)$ & 4 & $(50 \%)$ & $08(100 \%)$ \\
\hline $91-110$ & 1 & $(50 \%)$ & 1 & $(50 \%)$ & $02(100 \%)$ \\
\hline$>110$ & 0 & 0 & 0 \\
\hline TOTAL & $18(64 \%)$ & $10(36 \%)$ & $28(100 \%)$ \\
\hline
\end{tabular}

The table (Table-3) reveals that higher proportion of people having low serum iron ( less than $50 \mu \mathrm{gm} / \mathrm{dl}$ ) were having DNA damage in comparison to individuals having serum iron above $71 \mu \mathrm{gm} / \mathrm{dl}$. However, when $\chi^{2}$ test was applied to the sub-groups in the table, the results were not found to be statistically significant at $p=0.05$ level.

Figure-1 : DNA Comet Assay of normal individual

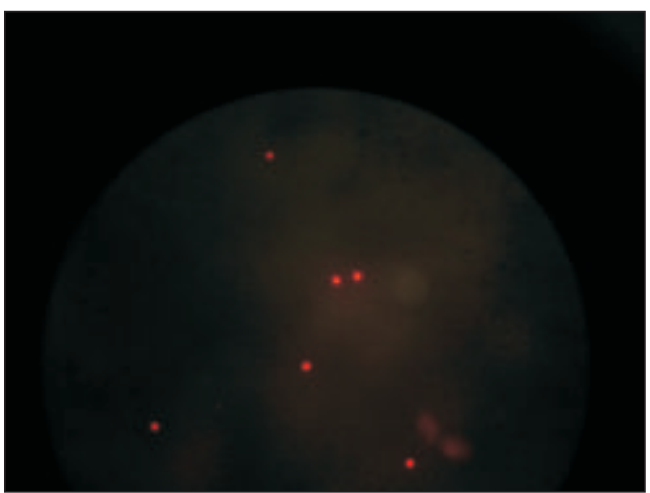

Figure 3: DNA Comet Assay of subject with DNA damage

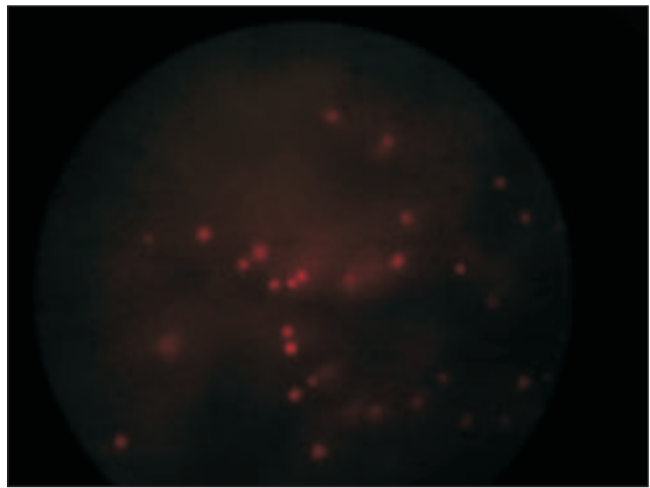

References:

1. Finkel T, Holbrook NJ; "Oxidants, oxidative stress and the biology of ageing." Nature,(2000); 408:239-247.

2. Evans P,Halliwell B; "Micronutrients:Oxidant/antioxidant status", British Journal of Nutrition;(2001); 85: 67-74

3. Tomi-Pekka Tuomainen ,Loft S,Nyyssonen K, Punnonen K, et al; "Body iron as a contributor to oxidative damage of DNA"; $\quad$ Free Radical Research; (2007); 41(3): 324 - 328

4. Aksu BY, Hasbal C, Himmetoglu S, Dincer Y et al; "Leukocyte DNA damage in children with iron deficiency anemia: effect of iron supplementation." EurJ Pediatr.(2010); 169 (8) : 951- 956

5. Mehmet Aslan , Mehmet Horoz, Abdurrahim Kocyigit, Saadet Ozgonül, Hakim Celik, Metin Celik, Ozcan Erel; "Lymphocyte DNA damage and oxidative stress in patients with iron deficiency anemia",Mutation Research / Fundamentals and Molecular Mechanisms of M utagenesis; (2006); 601 (1-2) : 144-149.

6. Perry, R.D. and San, C.L. "Determination of iron with bathophenanthroline following an improved procedure for reduction of iron (III) ions." The Analyst,(1977); 102 (1211): 114.
Figure-2 : DNA Comet Assay of subject with DNA damage

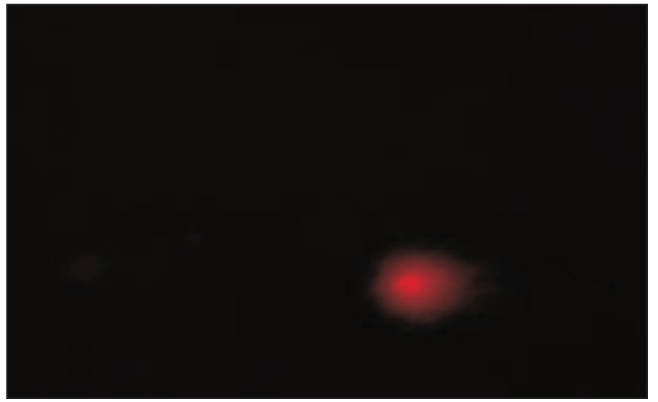

7. Clinical Chemistry ,2 $2^{\text {nd }}$ Edition,( Ed. R.J. Henry); 1974; pp:679-695 Harper and Rows

8. Singh, N.P., McCoy, M.T., Tice, R.R. and Schneider, E.L. "A simple technique for quantitation of low levels of DNA damage in individual cells." Exp. Cell Res.(1998); 175 : 184-191.)

9. Jong-Ha Yoo, Ho-Young M aeng ,Young-Kyu Sun, Young-Ah Kim , DongWook Park, Tae Sung Park, Seung Tae Lee ,Jong-RakChoi; "“"Oxidative status in iron-deficiency anemia"; Journal of Clinical Laboratory Analysis, (2009), 23 (5): 319-323.

10. Rech Franke SI, Pegas Henriques JA, Fenech M; "A possible link between iron deficiency and gastrointestinal carcinogenesis." Nutr Cancer. (2009); 61(4) : 415-426.

11. Esther Casanueva and Fernando E. Viteri; "Iron and Oxidative Stress in Pregnancy" J. Nutr. (2003); 133:1700S-1708S, (The American Society for Nutritional Sciences ). 